\title{
Effect of Female Education and Labor Force Ratio on Economic Development
}

\author{
Munevver Turanlia \\ Istanbul Commerce University \\ Dicle Taspinar Cengiz \\ Istanbul Commerce University \\ Rona Turanlic \\ Istanbul Yeni Yuzyil University

\section{Serem Akdal ${ }^{d}$} \\ Istanbul Commerce University
}

\begin{abstract}
This study investigates the effects of women's education and labor force ratio on the level of development in countries. We use a complete dataset covering 44 countries over the period 1990-2010. It comprises the following: education index, the ratio of girls to boys in primary and secondary education, income per capita, human development index, life expectancy at birth, population in the 0-14 and 15-64 age intervals, population over 64, number of seats held by women in parliaments, and female labor force ratio. We interpret this dataset using panel regression analysis, with the human development index as the depend ent variable. The variables are also subject to factor analysis and this results in three statistically significant factors-education and development, female labor force ratio, and population. We examine the rankings of factor scores for the countries covered and relevant to the issues in question. We then interpret their consequences. The countries are ranked using factor analysis and the results of the fixed effects model, which studies the changes that occurred between 1990 and 2010.
\end{abstract}

Keywords: Female education ratio $\bullet$ Female labor force ratio $\bullet$ Human development index $\bullet$ Factor analysis $\bullet$ Fixed effects model

\section{Corresponding author}

a Prof. Munevver Turanlı (PhD), Department of Statistics, Arts and Sciences Faculty, Istanbul Commerce University, Sutluce Mahallesi, Imrahor Caddesi, No: 90, Beyoglu Istanbul 34445 Turkey

Research areas: Decision techniques, statistical analysis

Email: mturanliaticaret.edu.tr

b Assoc. Prof. Dicle Taspinar Cengiz (PhD), Department of Statistics, Arts and Sciences Faculty, Istanbul Commerce University, Sutluce Mahallesi, Imrahor Caddesi, No: 90, Beyoglu Istanbul 34445 Turkey

Email: dtaspinardaticaret.edu.tr

c Prof. Rona Turanli (PhD), Department of Health Management, Faculty of Health Sciences, Yeni Yuzyil University, Yeni Dogan Mahallesi Yilanli Ayazma Caddesi, No: 26 Cevizlibaḡ, Zeytinburnu, Istanbul 34010 Turkey Email: turanlirdyahoo.fr

d Serem Akdal Email: seremakdaldgmail.com 
One of the most significant problems in developing countries is the level of education. Rapid population growth in such countries has declined the schooling rate and quality of education, besides leading to shortages in qualified labor.

Rapid population growth has also led to the problem of integrating a qualified female population into the production process of these countries. Unlike developed countries, women in less developed countries are constrained by the notions surrounding the concept of a traditional family. Hence, despite being educated, women face barriers to entering the labor force and participating in the production process.

This study seeks the "woman" factor in human development and investigates if this factor has any impact on economic development. Hence, only countries with complete records for the period under study are included. The data are subject to panel regression and factor analyses. After interpreting the panel regression model defined by such variables as the education ratios of girl students, female labor force ratio, and number of seats held by women in parliament, we factorize the multiple variables through dimension reduction and factor analyses. They reveal the factor scores as well as the rankings and groupings of countries. In addition, we study country rankings emerging from both analyses and from changes in the countries examined over the period under consideration. However, first, we will briefly examine the concept of development.

\section{Economic Development}

Economic development refers to improvements in cultural and political spheres besides growth of the economy. It can also be defined as the enhancement of welfare. In other words, the term development embraces improvements in socio-cultural spheres and in freedoms along with improvement in statistical indicators. For example, while the growth of a child may refer to his learning, his ability to read and write, his transitioning into adolescence, and to physical changes such as the growth of facial hair, it is his intelligence and contribution to his environment that is referred to as his development.

Although a concept of development that encompasses all countries is impossible, certain core factors can be isolated to illustrate the meaning of development (Case, Fair, \& Oster 2012, p. 715).

Some of the resources of economic development are capital accumulation, human resources, entrepreneurship, social capital, education, and the female labor force. In this study, we will consider only education and the female labor force.

Education: One of the most crucial factors in economic development is education. Education is the process of effecting a desired change in the behaviors of an individual through personal experience. Developing countries use educational policies in developmental strategies (Seyidoğlu, 1993, p. 27). There is a strong correlation between development and education. Thus, countries that value the education of girls will rank higher in terms of development.

Female Labor Force: Women are a significant factor in the dynamics and regulation of societies. Besides their role in shaping social life, women also play an important role in driving the development and advancement of countries. Worldwide, statistics show that there is a positive correlation between the value placed on women and the development of countries. Development is seen in those countries where women are appreciated and are active participants in the economic, social, and political spheres. In contrast, one sees poverty and misery in countries that do not view women favorably.

The contribution of women to the labor force dates back to the Industrial Revolution (1760-1840). As the demand for workers increased and as the male labor force fell short of demand, the need for women workers increased. An increase in the education of women and their participation in the labor force ensured rapid development of countries. Hence, it is important to take measures to improve the education of women and increase their contribution to the labor force (Özdemir, Yalman, \& Bayraktar, 2012). However, there is a significant difference between women's participation in employment as individuals with high-end positions or with worker status when one considers such positions as the indicators of the development of a country.

\section{Statistical Methods}

\section{Panel Data Analysis}

In econometric analyses, data can be divided into three groups: time series, cross-section, and mixed. If the variables are observed within a certain time period for a certain observation group, then such mixed data are called panel data. In other words, panel data combines sectional and time series analyses. Due to technology, panel data analysis has become a widely used mode of analysis. In such analysis, if there is no missing observation in 
the dataset, which means the dataset dimensions are the same for all countries, the dataset is called a balanced panel. However, if there are missing observations, and the dataset dimensions are not the same for all cases of observation, the dataset is called an unbalanced panel. The panel data model is given in equation 1 as follows:

$\mathrm{Y}_{\mathrm{it}}=\beta_{\text {lit }}+\beta_{2 \mathrm{it}} \mathrm{X}_{2 \mathrm{it}}+\ldots \ldots \ldots \ldots+\beta_{\text {kit }} \mathrm{X}_{\mathrm{kit}}+\mathrm{C}_{\mathrm{it}}$

$\mathrm{i}=1, \ldots \ldots \ldots, \mathrm{N}$

$\mathrm{t}=1, \ldots \ldots \ldots, \mathrm{T}$

In this equation, $\mathrm{N}$ denotes units and $\mathrm{t}$ denotes time. When variable $\mathrm{Y}$ is the dependent variable, with different values from unit to unit and from one time period to another, two sub-indices-i and t-are used to denote the section (observation) dimension and time period, respectively. It is possible to obtain different models by making different assumptions, particularly with respect to the properties of error terms and variability of coefficients, in studies conducted through panel data. Models obtained by making different assumptions are called models with "fixed effects" and "random effects." It is assumed that $\mathrm{e}_{\mathrm{it}}$ errors are distributed as $\mathrm{N}(0, \sigma 2)$, independent in both models for all time periods and individuals

While working with a panel dataset, various tests are administered to decide between fixed effects and random effects. The test statistic proposed by Hausman enables one to study the validity of the notion that error term components of a random effects model are not linked with the independent variables in the model. The Hausman model specification test helps one decide between fixed effects and random effects model for panel data analyses (Greene, 2003, pp. 72-73). It is important to study whether the difference between parameter estimators of a fixed effects model and those of a random effects model is statistically significant. While one prefers the high values of the Hausman statistic in a fixed effects model, lower values are preferred in random effects models. The Hausman test statistic tests the correlation between individual effects unique to cross-sectional ( $\varepsilon i$ ) and explanatory variables. This test is asymptotically $\chi 2$ distributed. Rejection of the null hypothesis makes one conclude that it is necessary to accept the fixed effects model vis-à-vis the random effects model. The following hypotheses can be defined:

H0: $\mathrm{E}(\varepsilon \mathrm{i} \mid \mathrm{Xit})=0$ Effects regarding the country and time are random.

There is no correlation between ( $\varepsilon i$ ) and explanatory variables.
H1: $\mathrm{E}(\varepsilon \mathrm{i} \mid \mathrm{Xit}) \neq 0$ Country and time effects are fixed.

There is a correlation between $(\varepsilon i)$ and explanatory variables.

The null hypothesis shows there is no correlation between the explanatory variables in the model and error terms. It is more appropriate to use random effects model in cases where the null hypothesis is accepted. In contrast, it is appropriate to use a fixed effects model if the null hypothesis is rejected. The Hausman test statistic implies a chi square distribution with $\mathrm{k}$ degrees of freedom under the null (0) hypothesis, "random effects estimator is acceptable." Upon its realization, one can decide that the error term components of a random effects model are uncorrelated with the independent variables. In such as case, a fixed effects model is chosen (Turhan \& Taşseven, 2010, p. 142).

\section{Factor Analysis}

Factor analysis is one of the most widely used multivariate statistical techniques that transforms interrelated multiple variables into fewer and more comprehensible significant factors independent of one another.

Factor analysis helps one identify representative variables to be used in other analyses, among many other variables. Factors obtained from the original dataset are used in a wide range of methods, including regression, correlation, and discriminant analysis as well as interdependent methods such as cluster analysis (Hair, Anderson, Tatham, \& Black, 1998, pp. 95-97). Factor analysis serves the function of revealing unobservable and immeasurable latent dimensions that lie behind many measurable and observable attributes.

Making classical assumptions such as normality, multicollinearity, and linearity leads to decline in correlations between variables in factor analysis. The normality assumption is required only if the significance of the factors to be derived will be tested. The assumption of multiple linear relations is desired as factor analysis reckons with the interrelationship of variables. Factor analysis is also appropriate if the correlation among variables is greater than 0.30 .

The more the correlation among variables is, the more likely it is for the variables to form common factors (Kalayc1, 2006, pp. 321-322). Hence, besides being a basic statistical principle, factor analysis is also indicated when the correlation matrix has adequate significant correlations. It is acceptable to 
extract variables, with correlation coefficients less than $30 \%$, using factor analysis.

The Kaiser-Mayer-Olkin (KMO) test is a sampling adequacy test used for measuring the correlations among variables and the applicability of factor analysis. The test value ranges between 0 and 1 . The KMO value equals 1 if any variable is estimated by other variables without any error. As shown below, the KMO test is done by comparing the calculated simple correlation coefficients with partial correlation coefficients.

$$
\mathrm{KMO}=\frac{\sum_{\mathrm{i} \neq \mathrm{j}} \sum \mathrm{r}_{\mathrm{ij}}^{2}}{\sum_{\mathrm{i} \neq \mathrm{j}} \sum \mathrm{r}_{\mathrm{j}}^{2}+\sum_{\mathrm{i} \neq \mathrm{j}} \sum \mathrm{a}_{\mathrm{j}}^{2}}
$$

where KMO denotes the Kaiser-Mayer-Olkin sampling adequacy test, $r_{i j}$ denotes the simple correlation coefficient between the variables $i$ and $\mathrm{j}$, and $\mathrm{a}_{\mathrm{ij}}$ denotes the partial correlation coefficient between the variables $i$ and $j$. When the relation between the variable pairs cannot be explained by other variables, the KMO value decreases. In such a case, factor analysis should not be used. By providing a measure of the average correlation between variables, the test measures the homogeneity of the variables. For an outstanding factor analysis, the KMO value should not be greater than 0.80 . However, values greater than 0.50 are acceptable.

Factor analysis uses the standardized $\mathbf{Z}_{\mathrm{pxn}}$ data matrix, which is obtained from the $\mathbf{X}_{\mathrm{pxn}}$ raw data matrix that gives the $\mathrm{p}$ number of variables of $\mathrm{n}$ individuals. In this case, the factor analysis model is a linear model that denotes the relation between $z_{j}$ variables and $\mathrm{f}_{1}, \mathrm{f}_{2}, \ldots, \mathrm{f}_{\mathrm{m}}$ common factors (Tatlidil, 2002, p. 168) and gives the correlation with the highest value (Pazarlığlu, Emeç, \& Erdoğan, 1999, p. 850). This model is generally depicted as follows:

$$
\begin{aligned}
& \mathrm{z}_{\mathrm{j}}=\mathrm{a}_{\mathrm{j} 1} \mathrm{f}_{1}+\mathrm{a}_{\mathrm{j} 2} \mathrm{f}_{2}+\ldots+\mathrm{a}_{\mathrm{j}} \mathrm{f}_{\mathrm{m}}+\mathrm{b}_{\mathrm{j}} \mathrm{u}_{\mathrm{j}} \\
& ; \mathrm{j}=1,2, \ldots, \mathrm{p} \\
& \text { where } \mathrm{z}_{\mathrm{j}} \text { : } \mathrm{j}^{\text {th }} \text { variable, }
\end{aligned}
$$

$a_{j m}$ : the loadings of the $j^{\text {th }}$ variable on the $\mathrm{m}^{\text {th }}$ variable,

\section{$\mathrm{f}$ : common factor}

$\mathrm{u}_{\mathrm{j}}$ : specific or residual factor

$b_{j}$ : coefficient related to specific or residual factor

$\mathrm{m}=$ the number of common factors

The value of $\mathrm{j}$ variable for $\mathrm{i}$ individual can be written as given below, following the classical factor analysis model:

$\mathrm{z}_{\mathrm{j}}=\sum_{\mathrm{p}=1}^{\mathrm{m}} \mathrm{a}_{\mathrm{p}} \mathrm{F}_{\mathrm{p}}+\mathrm{b}_{\mathrm{j}} \mathrm{u}_{\mathrm{j}} \quad(\mathrm{i}=1,2, \ldots, \mathrm{N} ; \mathrm{j}=1,2, \ldots, \mathrm{n})(1-3)$

This model can be clearly written as follows for any $z_{j}$ variable depending on $\mathrm{m}$ common factors and a unique factor:

$$
\begin{aligned}
& \mathrm{z}_{1}=\mathrm{a}_{1} \mathrm{~F}_{1}+\mathrm{a}_{\mathrm{\imath}} \mathrm{F}_{2}+\ldots \ldots \ldots+\mathrm{a}_{1 \mathrm{~m}} \mathrm{~F}_{\mathrm{m}}+\mathrm{b}_{1} \mathrm{U}_{1} \\
& \mathrm{z}_{2}=\mathrm{a}_{1} \mathrm{~F}_{1}+\mathrm{a}_{2} \mathrm{~F}_{2}+\ldots \ldots \ldots+\mathrm{a}_{2 \mathrm{~m}} \mathrm{~F}_{\mathrm{m}}+\mathrm{b}_{2} \mathrm{U}_{2}
\end{aligned}
$$

$\mathrm{z}_{\mathrm{n}}=\mathrm{a}_{\mathrm{n} 1} \mathrm{~F}_{1}+\mathrm{a}_{\mathrm{n} 2} \mathrm{~F}_{2}+\ldots \ldots .+\mathrm{a}_{\mathrm{m}} \mathrm{F}_{\mathrm{m}}+\mathrm{b}_{\mathrm{n}} \mathrm{U}_{\mathrm{n}}$

This set of equations is called a factorial pattern or just pattern. Here, the common factors $\mathrm{F}_{\mathrm{p}}(\mathrm{p}=$ $1,2, \ldots, \mathrm{m})$ may or may not be correlated. Yet, the unique factor $U_{j}(j=1,2, \ldots, n)$ is always accepted as uncorrelated both with themselves and with other common factors. Factor analysis does not only yield a pattern but also produces the relationship between variables and factors. The table depicting this relation is called a factorial structure or just structure, and is required for completing both the pattern and the structural resolution (Atan, Göksel, \& Karpat, 2002)

The factors are denoted and interpreted by considering factor loadings. Thus, if the correlation of the variable with the common factor is greater than \pm 0.30 , it is accepted that the variable has significant correlation with the common factor in question. Some researchers say this proportion should be greater than \pm 0.40 or even \pm 0.50 . Negative factor weights should also be while including positive factor loadings that are greater than \pm 0.30 . The common factor should be interpreted as showing a positive relation with positive factor weights and a negative relation with negative factor weights. Hence, the factors can be viewed as being dipolar (Albayrak, 2000, pp. 124-125).

\section{Analysis and Findings}

We looked at panel data for 44 countries over the period 1990 and 2010 to examine the effects of women's education and labor force ratio on the development of these countries. The data were obtained annually from the databanks of the United Nations Development Program (UNDP) and the World Bank. An optimal model was chosen using the E-Views 07 econometric analysis software. In the optimal model, which can be accessed in full for 12 variables, three were found to be statistically significant $(p<.001)$. Meanwhile, factor analysis 
was also applied to the 12 variables to see the profile of all the variables. Thus, factor scores helped to compare the ranking of countries, in terms of the fixed effect, with the sequence. Significant factorizations resulted from applying factor analysis to the 12 identified variables. The countries were ranked on the basis of the following factors:

The variables used in the study are defined as follows:

\section{$\mathrm{X} 1$ : Education index}

$\mathrm{X} 2$ : The ratio of girls to boys in primary education

$\mathrm{X} 3$ : The ratio of girls to boys in secondary education

$\mathrm{X} 4$ : Income per capita (in dollars)

X5: Human development index ${ }^{*}$

X6: Life expectancy at birth

X7: The ratio of population aged 0-14 to total population

X8: The ratio of population aged 15-64 to total population

X9: Population aged over 64

X10: Total population

X11: Proportion of seats held by women in national parliaments (\%)

X12: Ratio of female to male labor participation rate (\%)

Factor analyses were applied separately to 12 variables that could explain development for five different periods (1990, 1995, 2000, 2005, and 2010) to explain development. A factorization outcome was obtained for each period. The results revealed three factors with which the variables could coexist. These factors, given in Table 1, were education and development, female labor force ratio, and the general population. This classification was based on a study of the factor components. As similar loadings were found for the five different periods studied, only the component matrix obtained from the data for the year 2010 is provided in Table 1.

* The United Nations Development Program has been publishing an annual report called the Human development report since1990. The UNDP's Human Development Index helps compare social and economic development levels across countries. In its report, the UNDP states that it is inappropriate to measure the level of development across countries based on an increase in income per capita (economic growth). A high national income is not enough to call a country developed. Social and economic developments are better measures of welfare and living standards across countries than economic growth.
Rankings based on factor loadings in the countries studied are given in Table 2. As the variables compiled in the first factor are linked to education and development, the ranking of countries are based on such factor loadings of the countries. Countries are ranked based on separate factor loadings for each year. It is possible to compare changes in countries over the years in one single table where such rankings are indicated. The European Union member countries are indicated in bold. The table also shows the proximity of other countries to EU member countries.

\begin{tabular}{cccc}
\hline $\begin{array}{l}\text { Table } 1 \\
\text { Component Matrix of } 2010\end{array}$ & \multicolumn{3}{c}{ Component } \\
\cline { 2 - 4 } & 1 & 2 & 3 \\
\hline $\mathrm{x} 1$ & .966 & .065 & .007 \\
$\mathrm{x} 7$ & -.950 & .048 & .261 \\
$\mathrm{x} 6$ & .929 & -.225 & -.081 \\
$\mathrm{x} 4$ & .888 & .283 & -.090 \\
$\mathrm{x} 9$ & .872 & .242 & -.217 \\
$\mathrm{x} 8$ & .833 & -.356 & -.253 \\
$\mathrm{x} 12$ & -.049 & .902 & .030 \\
$\mathrm{x} 11$ & .319 & .691 & .271 \\
$\mathrm{x} 10$ & .121 & -.319 & .304 \\
$\mathrm{x} 3$ & .483 & -.248 & .698 \\
$\mathrm{x} 2$ & .487 & .018 & .696 \\
\hline
\end{tabular}

We used E-Views 07 software to compile data for the panel regression analysis. The significant model, with variables related to female rates as independent variables and with the ones related to human development index as dependent variables, is given in Table 3 and interpreted.

Analyzing the significance of coefficients in the model equation, we can draw the following inferences: The contribution of the variable $\mathrm{X} 2$, which is the ratio of girls to boys in primary education, to the model equation is insignificant. It is included in the model because of higher probability of type II error of this variable. While the ratio of girls to boys in secondary education (X3) is significant, the ratio of girls to boys in primary education (X2) is also intended to be shown as approximately significant. The contribution of other variables to the model equation is significant. 
Table 2

Rankings of Countries by Year for the First Factorization (Education and Development)

\begin{tabular}{|c|c|c|c|c|}
\hline 1990 & 1995 & 2000 & 2005 & 2010 \\
\hline Norway & Japan & Sweden & Norway & Norway \\
\hline Sweden & Sweden & Norway & Spain & Japan \\
\hline Switzerland & United States & Belgium & Sweden & Sweden \\
\hline United States & Norway & Spain & Japan & Switzerland \\
\hline Finland & Belgium & Japan & Finland & Netherlands \\
\hline Netherlands & Italy & Finland & United States & Spain \\
\hline Japan & Switzerland & United States & Switzerland & Finland \\
\hline Belgium & Spain & Netherlands & Australia & United States \\
\hline Italy & Finland & Switzerland & Austria & Austria \\
\hline Australia & Netherlands & Australia & Belgium & Australia \\
\hline Austria & Australia & Austria & Italy & Belgium \\
\hline France & Austria & Italy & Netherlands & Italy \\
\hline Spain & France & New Zealand & New Zealand & New Zealand \\
\hline New Zealand & Greece & Greece & Greece & Korea (Republic of) \\
\hline Greece & New Zealand & France & France & France \\
\hline Hungary & Portugal & Portugal & Portugal & Greece \\
\hline Bulgaria & Hungary & Malta & Korea (Republic of) & Portugal \\
\hline Portugal & Korea (Republic of) & Korea (Republic of) & Cyprus & Cyprus \\
\hline Cyprus & Cyprus & Hungary & Malta & Malta \\
\hline Malta & Bulgaria & Cyprus & Hungary & Hungary \\
\hline Korea (Republic of) & Malta & Bulgaria & Bulgaria & Bulgaria \\
\hline Uruguay & Uruguay & Uruguay & Costa Rica & Costa Rica \\
\hline Colombia & Costa Rica & Costa Rica & Uruguay & Uruguay \\
\hline Costa Rica & Dominica & Mexico & Tunisia & Tunisia \\
\hline Mexico & Mexico & Tunisia & Mexico & Mexico \\
\hline Dominica & Colombia & Dominica & Algeria & Algeria \\
\hline Paraguay & Tunisia & Colombia & Dominica & Colombia \\
\hline Indonesia & Indonesia & Indonesia & Colombia & Turkey \\
\hline Nicaragua & Paraguay & Algeria & Indonesia & Indonesia \\
\hline Honduras & Turkey & Paraguay & Turkey & Dominica \\
\hline Tunisia & Nicaragua & Turkey & Paraguay & Paraguay \\
\hline Turkey & Honduras & Nicaragua & Honduras & Egypt \\
\hline Egypt & Algeria & Honduras & Egypt & Syrian Arab Rep. \\
\hline Algeria & Egypt & Egypt & Nicaragua & Honduras \\
\hline Syrian Arab Rep. & Syrian Arab Rep. & Syrian Arab Rep. & Syrian Arab Rep. & Nicaragua \\
\hline Madagascar & Madagascar & Morocco & Morocco & Morocco \\
\hline Morocco & Morocco & Madagascar & Madagascar & Senegal \\
\hline Lao People's D.Rep. & Lao People’s D.Rep. & Lao People’s D.Rep. & Senegal & Madagascar \\
\hline Uganda & Malawi & Senegal & Lao People's D.Rep. & Lao People's D.Rep. \\
\hline Senegal & Senegal & Uganda & Uganda & Uganda \\
\hline Malawi & Uganda & Malawi & Malawi & Malawi \\
\hline Togo & Togo & Togo & Togo & Togo \\
\hline Mozambique & Mozambique & Mozambique & Guinea & Mozambique \\
\hline Guinea & Guinea & Guinea & Mozambique & Guinea \\
\hline
\end{tabular}

Parameters are estimated by using both the fixed effects and random effects model to understand the effects of observation in panel data. The Hausman test is performed to decide which of the two models is statistically valid. In the Hausman test, the null hypothesis is that the preferred model is the "random effects model," whereas the alternative hypothesis is that the preferred model is the "fixed effects model." Table 4 gives the Hausman test results. 
Table 3

Outcome of Panel Regression Analysis

Dependent Variable: X5

Method: Pooled Least Squares

Sample: 1990-2010

Included observations: 4

Cross-sections included: 44

Total pool (balanced) observations: 176

\begin{tabular}{|c|c|c|c|c|}
\hline Variable & Coefficient & Std. Error & $t$-Statistic & Prob. \\
\hline $\mathrm{X} 2$ & 0.002278 & 0.001555 & 1.464 .839 & 0.1448 \\
\hline $\mathrm{X} 3$ & 0.005413 & 0.001470 & 3.683 .261 & 0.0003 \\
\hline $\mathrm{X} 11$ & 0.005275 & 0.001103 & 4.783 .640 & 0.0000 \\
\hline $\mathrm{X} 12$ & -0.002035 & 0.000533 & -3.815 .853 & 0.0002 \\
\hline R-squared & 0.476646 & \multicolumn{2}{|c|}{ Mean dependent var } & 0.686199 \\
\hline Adjusted R-squared & 0.467518 & \multicolumn{2}{|c|}{ S.D. dependent var } & 0.188961 \\
\hline S.E. of regression & 0.137887 & \multicolumn{2}{|c|}{ Akaike info criterion } & -1.102 .298 \\
\hline Sum squared residuals & 3.270 .212 & \multicolumn{2}{|c|}{ Schwarz criterion } & -1.030 .241 \\
\hline Log likelihood & 1.010 .022 & \multicolumn{2}{|c|}{ Hannan-Quinn criterion } & -1.073 .072 \\
\hline Durbin-Watson statistic & 0.104900 & & & \\
\hline
\end{tabular}

$\mathrm{X} 5=0.002278 \mathrm{X} 2+0.005413 \mathrm{X} 3+0.005275 \mathrm{X} 11-0.002035 \mathrm{X} 12$

\begin{tabular}{|c|c|c|c|c|}
\hline \multicolumn{5}{|c|}{$\begin{array}{l}\text { Table } 4 \\
\text { Hausman Test Results }\end{array}$} \\
\hline \multicolumn{5}{|c|}{ Correlated Random Effects - Hausman Test } \\
\hline \multicolumn{5}{|l|}{ Pool: HDI } \\
\hline \multicolumn{5}{|c|}{ Test cross-section random effects } \\
\hline \multicolumn{2}{|c|}{ Test Summary } & $\begin{array}{l}\text { Chi-Sq. } \\
\text { Statistic }\end{array}$ & Chi-Sq. d.f. & Prob. \\
\hline \multicolumn{2}{|c|}{$\begin{array}{l}\text { Cross-section ran- } \\
\text { dom }\end{array}$} & 48.148 .782 & 4 & 0.0000 \\
\hline \multicolumn{5}{|c|}{ Cross-section random effects test comparisons: } \\
\hline Variable & Fixed & Random & Var (Diff.) & Prob. \\
\hline $\mathrm{X} 2$ & 0.003363 & 0.003424 & 0.000000 & 0.7693 \\
\hline $\mathrm{X} 3$ & 0.001440 & 0.001692 & 0.000000 & 0.0865 \\
\hline $\mathrm{X} 11$ & 0.001681 & 0.002872 & 0.000000 & 0.0000 \\
\hline $\mathrm{X} 12$ & 0.003713 & 0.001499 & 0.000000 & 0.0000 \\
\hline
\end{tabular}

As probability $=.000<.05$ is seen, $\mathrm{H}_{0}$ hypothesis is rejected, which means the model will be estimated through the fixed effects.

Table 5 gives the fixed effects estimation results.

Analyzing the coefficients of the model, we find that each of the variables makes a significant contribution to the fixed effect model. Table 6 gives the ranking of countries, from low to high, based on the model's fixed effects value.

\section{Discussion}

Economic development, or the enhancement of welfare, refers to improvements in the social, cultural, and political spheres along with economic growth. This study reveals the effect of women's education and labor force participation on the economic and human development levels of countries statistically over a period of roughly 20 years, or 1990 to 2010.We examined 44 countries, whose data could be accessed for the given time period. The 12 variables of the component scores were compiled into three factors based on the results of factor analysis. This result, yielded as the same factorization for five different years, demonstrating that the correlation among the developmental indicators did not change over the years. The following variables were compiled for the first factor, seen as the most important: education index (x1), the ratio of population in the $0-14$ age interval to total population (x7), life expectancy at birth (x6), income per capita (x4), population aged over 64 (x9), and the ratio of population in the 15-64 age interval to total population (x8). Among these, only the ratio of population in the 0-14 age interval to total population had a negative impact $(-0.95)$ on the relevant factor. The loadings of other variables were positive with rather high ratios (see Table 3). Numerical values show that an increase in the population of children is inversely correlated with the indicators of development. As for the rankings of countries based on the scores of this factor, no marked change was observed over the years (see Table 4). However, Tunisia, Korea, and Spain displayed marked differences. All these three countries made seven levels of progress between 1990 and 2010. Similarly, Algeria made a progress of eight levels. Colombia, Nicaragua, Honduras, and Dominica were the countries that regressed in the rankings between 1990 and 2010. Turkey made a progress of four levels. Overall, members of the 
Table 5

Fixed Effects Estimation Results

Dependent Variable: X5

Method: Pooled Least Squares

Sample: 19902010

Included observations: 4

Cross-sections included: 44

Total pool (balanced) observations: 176

\begin{tabular}{lllll}
\hline Variable & Coefficient & Std. Error & t-Statistic & Prob. \\
C & -0.552255 & 0.136442 & -4.047 .557 & 0.0001 \\
X2 & 0.008161 & 0.002083 & 3.917 .556 & 0.0001 \\
X3 & 0.004864 & 0.001436 & 3.387 .571 & 0.0009 \\
X11 & 0.004236 & 0.001153 & 3.672 .605 & 0.0003 \\
X12 & -0.001205 & 0.000554 & -2.176 .637 & 0.0309 \\
\hline
\end{tabular}

\begin{tabular}{|c|c|c|c|}
\hline Fixed Effects (Cross) & & & \\
\hline _ALGERIA--C & -0.050708 & \multirow{3}{*}{\multicolumn{2}{|c|}{ Effects Specification }} \\
\hline _AUSTRALIA--C & 0.223283 & & \\
\hline _AUSTRIA--C & 0.168468 & & \\
\hline _BELGIUM--C & 0.184855 & \multirow{4}{*}{\multicolumn{2}{|c|}{$\begin{array}{l}\text { Cross-section fixed (dummy variables) } \\
\text { Period fixed (dummy variables) }\end{array}$}} \\
\hline _BULGARIA--C & 0.051394 & & \\
\hline _COLOMBIA--C & -0.043155 & & \\
\hline _COSTARICA--C & 0.029142 & & \\
\hline _CYPRUS--C & 0.110632 & & \\
\hline _DOMINICA--C & 0.002666 & \multirow{7}{*}{\begin{tabular}{|ll} 
R-squared & 0.989069 \\
Adjusted R-squared & 0.984697 \\
S.E. of regression & 0.023375 \\
Sum squared re- & 0.068301 \\
sidual & \\
Log likelihood & 4.414 .464 \\
F-statistic & 2.262 .139 \\
Prob (F-statistic) & 0.000000 \\
\end{tabular}} & Mean dependent var \\
\hline _EGYPT--C & -0.095694 & & S.D. dependent var \\
\hline _FINLAND--C & 0.176038 & & Akaike info criterion \\
\hline _FRANCE--C & 0.153544 & & Schwarz criterion \\
\hline _GREECE--C & 0.128102 & & Hannan-Quinn criterion \\
\hline _GUINEA--C & -0.355530 & & Durbin-Watson statistic \\
\hline _HONDURAS--C & -0.124159 & & \\
\hline _HUNGARY--C & 0.091094 & & \\
\hline _INDONESIA--C & -0.139496 & & \\
\hline _ITALY--C & 0.142734 & & \\
\hline _JAPAN--C & 0.175607 & Fixed Effects (Period) & \\
\hline _KOREAREPUBLIC--C & 0.141052 & $1990--\mathrm{C} \quad-.066161$ & \\
\hline _LAOPEOPLED.REP--C & -0.193761 & 2000--C & \\
\hline _MADAGASCAR--C & -0.268260 & 0.023023 & \\
\hline _MALAWI--C & -0.324793 & 0.046493 & \\
\hline _MALTA--C & 0.107122 & & \\
\hline _MEXICO--C & 0.031487 & & \\
\hline _MOROCCO--C & -0.150376 & & \\
\hline _MOZAMBIQUE--C & -0.373395 & & \\
\hline _NETHERLANDS--C & 0.212725 & & \\
\hline _NEWZEALAND--C & 0.202009 & & \\
\hline _NICARAGUA--C & -0.153831 & & \\
\hline _NORWAY--C & 0.243860 & & \\
\hline _PARAGUAY--C & -0.074418 & & \\
\hline _PORTUGAL--C & 0.088239 & & \\
\hline _SENEGAL--C & -0.255158 & & \\
\hline _SPAIN--C & 0.154240 & & \\
\hline _SWEDEN--C & 0.213341 & & \\
\hline _SWITZERLAND--C & 0.197393 & & \\
\hline _SYRIANARABREP.--C & -0.084606 & & \\
\hline _TOGO--C & -0.238756 & & \\
\hline _TUNISIA--C & -0.039439 & & \\
\hline _TURKEY--C & -0.034268 & & \\
\hline _UGANDA--C & -0.290358 & & \\
\hline _UNITEDSTATES--C & 0.016330 & & \\
\hline _URUGUAY--C & 0.044805 & & \\
\hline
\end{tabular}




\begin{tabular}{|c|c|c|}
\hline \multicolumn{3}{|c|}{$\begin{array}{l}\text { Table } 6 \\
\text { The Ranking of Countries }\end{array}$} \\
\hline 1 & _MOZAMBIQUE--C & -0.3734 \\
\hline 2 & _GUINEA--C & -0.35553 \\
\hline 3 & _MALAWI--C & -0.32479 \\
\hline 4 & _UGANDA--C & -0.29036 \\
\hline 5 & _MADAGASCAR--C & -0.26826 \\
\hline 6 & _SENEGAL--C & -0.25516 \\
\hline 7 & _TOGO--C & -0.23876 \\
\hline 8 & _LAOPEOPLEDEMREP--C & -0.19376 \\
\hline 9 & _NICARAGUA--C & -0.15383 \\
\hline 10 & _MOROCCO--C & -0.15038 \\
\hline 11 & _INDONESIA--C & -0.1395 \\
\hline 12 & _HONDURAS--C & -0.12416 \\
\hline 13 & _EGYPT--C & -0.09569 \\
\hline 14 & _SYRIANARABREPUBLIC-- & -0.08461 \\
\hline 15 & _PARAGUAY--C & -0.07442 \\
\hline 16 & _ALGERIA--C & -0.05071 \\
\hline 17 & _COLOMBIA--C & -0.04316 \\
\hline 18 & _TUNISIA--C & -0.03944 \\
\hline 19 & _TURKEY--C & -0.03427 \\
\hline 20 & _DOMINICA--C & 0.002666 \\
\hline 21 & _UNITEDSTATES--C & 0.01633 \\
\hline 22 & _COSTARICA--C & 0.029142 \\
\hline 23 & _MEXICO--C & 0.031487 \\
\hline 24 & _URUGUAY--C & 0.044805 \\
\hline 25 & _BULGARIA--C & 0.051394 \\
\hline 26 & _PORTUGAL--C & 0.088239 \\
\hline 27 & _HUNGARY--C & 0.091094 \\
\hline 28 & _MALTA--C & 0.107122 \\
\hline 29 & _CYPRUS--C & 0.110632 \\
\hline 30 & _GREECE--C & 0.128102 \\
\hline 31 & _KOREAREPUBLIC--C & 0.141052 \\
\hline 32 & _ITALY--C & 0.142734 \\
\hline 33 & _FRANCE--C & 0.153544 \\
\hline 34 & _SPAIN--C & 0.15424 \\
\hline 35 & _AUSTRIA--C & 0.168468 \\
\hline 36 & JJAPAN--C & 0.175607 \\
\hline 37 & _FINLAND--C & 0.176038 \\
\hline 38 & _BELGIUM--C & 0.184855 \\
\hline 39 & _SWITZERLAND--C & 0.197393 \\
\hline 40 & _NEWZEALAND--C & 0.202009 \\
\hline 41 & _NETHERLANDS--C & 0.212725 \\
\hline 42 & _SWEDEN--C & 0.213341 \\
\hline 43 & _AUSTRALIA--C & 0.223283 \\
\hline 44 & _NORWAY--C & 0.24386 \\
\hline
\end{tabular}

European Union, the USA, Japan, and Australia enjoyed high rankings, which was a notable finding.

The results of the panel regression analysis show the insignificance of the ratio of girls in primary education in the model. This can be interpreted as primary education, compulsory in most countries, losing its discriminative effect on development. Although this variable was found to be insignificant, the ratio of girls to boys in secondary education turned out to be a significant variable in the model. Thus, if girls continue their education, it will have an effect on development. The negative value ( $\beta$ $=-.002 ; p<.001)$ of the coefficient related to the ratio of women workers was found to be significant in the model, indicating that an increase in the rate of participation of women laborers is inversely correlated with human development. Thus, women are employed as laborers in underdeveloped countries. However, the more developed a country is, the more are the women employed in higher-end jobs. There are great similarities in the ranking of countries based on the results of factor analysis and according to the fixed-effect coefficients, even when the variables vary. Developed countries occupy the top row, while the less developed countries populate the bottom row. As for Turkey, she keeps the same rank after each analysis. Therefore, irrespective of the variables supporting women's education, it is still an indicator of the level of development of a country. 


\section{References}

Albayrak, A. S. (2000). Uygulamal çok değişkenli istatistik teknikleri. Ankara: Asil Yayınevi.

Atan, M., Göksel, A., Karpat, G. (2002). Üniversite öğrencilerinin başarılarını etkileyen faktörlerin çok değişkenli istatistiksel analiz yöntemleri ile tespiti. In XI. Eğitim Bilimleri Kongresi (pp. 3-4). TRNC Mersin, Turkey: Near East University.

Case, K. E., Fair, R. C., \& Oster, S. M. (2012). Ekonominin ilkeleri (trans. E. Çeliktaş, M. Güçlü, \& M. Karadağ). Ankara: Palme Yayıncilı.

Hair, J. F., Anderson, R. E., Tatham, R. L., \& Black, W. C. (1998). Multivariate data analysis. New Jersey, NJ: Prentice Hall.

Greene, W. H. (2002). Econometric analysis. New Jersey, NJ: Prentice Hall.

Kalaycı, Ş. (Ed.). (2006). SPSS uygulamalı çok değişkenli istatistik teknikleri (2nd ed.). Ankara: Asil Yayın Dağıtım.
Özdemir, Z., Yalman, İ. N., \& Bayrakdar, S. (2012, October). Kadın istihdamı ve ekonomik kalkınma. Paper presented at the International Conference on Eurasian Economies. Retrieved from http://www.eecon.info/papers/476.pdf

Pazarlıoğlu, M. V., Emeç, H., \& Erdoğan, S. (1999, May). Dokuz Eylül Üniversitesi öğrencilerinin yüksek öğretim beklenti değisskenlerinin faktör analizi ile incelenmesi. In IV. Ulusal Ekonometri ve İstatistik Sempozyumu Bildirileri (p. 850). Antalya-Belek: Marmara Üniversitesi.

Seyidoğlu, H. (1993). Uluslararast iktisat (9th. ed.). İstanbul: Gizem Yayınları.

Tatlıdil, H. (2002). Uygulamalı çok değişkenli istatistiksel analiz. Ankara: Ziraat Matbaacilık.

Turhan, M., \& Taşseven, Ö. (2010). Yönetim fonksiyonlarının uygulandığı alanlarda ortaya çıkan hata değerlerinin oluşturduğu yeni ilișkilerin panel veri modelleri ile irdelenmesi. İstanbul Üniversitesi İktisat Fakültesi Ekonometri ve İstatistik Dergisi, 11, 128-153. 